\title{
PENGEMBANGAN MINUMAN TEH HITAM DENGAN DAUN KELOR (MORINGA OLEIFERA L) SEBAGAI MINUMAN MENYEGARKAN
}

\author{
Yessy Friskilla', Rahmawati ${ }^{2}$ \\ Jurusan Teknologi Pangan Universitas Sahid Jakarta \\ Jl. Soepomo No 84, Jakarta Selatan \\ Email Korespondensi: rahmafarasara@usahid.ac.id
}

\begin{abstract}
ABSTRAK
Saat ini pemanfaatan daun kelor sebagai produk makanan minuman karena manfaatnya yang baik untuk kesehatan sedang berkembang. Berdasarkan hal tersebut, maka dibuat pengembangan minuman teh hitam dengan daun kelor. Untuk mengetahui mutu teh hitam daun kelor, maka dibuat berbagai formulasi. Tujuan penelitian untuk mengetahui bagaimana pengaruh formulasi daun kelor dan teh hitam terhadap mutu teh yang dihasilkan. Formulasi daun kelor dengan teh hitam, yaitu 75:25, 80:20, 85:15, 90:10, 95:5. Data dianalisis dengan analisis varian (ANAVA). Jika hasil uji ANAVA menunjukkan perbedaan nyata maka dilanjutkan dengan uji Duncan. Hasil penelitian menunjukkan formulasi daun kelor dengan teh hitam berbeda nyata $(\alpha=0,05)$ terhadap kekentalan, kadar karbohidrat, total padatan terlarut, kadar tanin, warna dan rasa secara organoleptik. Formulasi teh daun kelor teh hitam 85:15 paling disukai. Minuman ini berwarna coklat, beraroma agak langu, dan berasa agak sepat, dengan kekentalan $1,90 \mathrm{cP}$, kadar air 3,21\%, abu $7,51 \%$, lemak $1,12 \%$, protein $8,68 \%$, karbohidrat $8,02 \%, \mathrm{pH} 7,18$, total padatan terlarut 5,31\% dan kadar tanin 3,89 ppm. Disarankan untuk membuat teh hitam daun kelor dalam bentuk teh celup sehingga penyajiannya menjadi lebih cepat, mudah dan praktis.
\end{abstract}

Kata kunci : kewirausahaan, teh hitam, daun kelor, minuman menyegarkan

\begin{abstract}
Currently the utilization of Moringa leaves as a food or beverage product is growing because of its good benefits for health. Based on this, then made the development of black tea drinks with moringa leaves. To determine the quality of black tea with moringa leaves, then made various formulations products. The purpose of this research is to know how the effect of leaf and black tea formulation on the quality of tea produced. Moringa leaf formulation with black tea, which are $75: 25,80: 20,85: 15,90: 10,95: 5$. Data were analyzed by analysis of variance (ANAVA). If the ANAVA test results showed that there are significantly differences, then proceed with Duncan test. The results showed that moringa leaves with black tea formulation were significantly different $(\alpha=0,05)$ to viscosity, carbohydrate, total soluble solid, tannin contents, color and taste organoleptically. The moringa leaves and black tea formulation 85:15 is most preferred. This drink is brown, slightly flavored and slightly bitter, with $1.90 \mathrm{cP}$ thickness, $3.21 \%$ moisture, $7.51 \%$ ash, $1.12 \%$ fat, $8.68 \%$ protein, 8.02 carbohydrates \% contents, $p H 7.18$, total dissolved solids 5,31\% and tannin 3,89 ppm. It is advisable to make black tea moringa leaves in the form of tea bags. It will becomes faster, easier and practical when consumed.
\end{abstract}

Keywords : entrepreneurship, black tea, moringa leaves, formulation 


\section{PENDAHULUAN}

Minuman teh merupakan minuman yang digemari hampir semua golongan umur karena selain memberikan efek menyegarkan juga mempunyai manfaat kesehatan. Salah satu jenis the yang disukai masyarakat adalah teh hitam. Teh hitam dibuat dari pucuk daun teh yang mengalami proses fermentasi. Selama proses fermentasi, enzim polifenol oksidase akan mengoksidasi katekin dalam daun segar. Katekin terurai menjadi senyawa theaflavin yang berperan memberi warna kuning dan senyawa thearubigin memberi warna merah kecoklatan (Tuminah, 2004). Selain teh hitam mengandung kafein. Ketiga senyawa ini memberikan efek menyegarkan pada saat the diminum (Sujayanto, 2008). Selain, itu teh hitam dikenal dapat menurunkan resiko penyakit jantung koroner, mencegah dan mengontrol pertumbuhan kanker, mencegah karies gigi, peningkatan massa tulang, serta efek anti diabetes (Machfoedz, 2008). Pembuatan aneka minuman teh saat ini mulai berkembang karena konsumen selalu menginginkan adanya produk baru. Berdasarkan hal tersebut, telah dilakukan penelitian dengan membuat minuman teh dengan mencampur bahan lain seperti daun murbai (Damayanti dkk 2008), daun jeruk purut (Roni 2008), daun sirsak (Manik 2014), dan kulit buah naga (Putri 2014).

Saat ini pemanfaatan daun kelor sebagai produk makanan dan minuman sedang berkembang karena daun kelor mempunyai manfaat yang baik untuk kesehatan. Menurut Simbolan, dkk. (2007) daun kelor bermanfaat untuk mengobati berbagai penyakit diantaranya yaitu demam, radang usus, reumatik, pegal linu, diare, rabun ayam, disentri, diabetes, bronchitis, radang selaput lendir, pencuci perut, meningkatkan air susu ibu (ASI). Daun kelor (Moringa Oleifera L) merupakan tanaman khas daerah tropis yang juga mudah tumbuh di Indonesia. Daun kelor sudah dikenal luas di Indonesia khususnya di daerah pedesaan, tetapi belum banyak dimanfaatkan sebagai produk olahan pangan. Belum ada data yang menunjukkan dengan pasti jumlah sebaran produktivitas pohon kelor di Indonesia, namun tanaman kelor banyak dijumpai di Aceh, Kalimantan, Ujung Pandang, Pulau Jawa dan Kupang. Melihat manfaat yang besar dari daun kelor maka dicoba untuk dibuat menjadi teh, namun daun kelor tidak mempunyai rasa khas teh. Untuk meningkatkan cita rasa teh maka ditambahkan teh hitam.

Masalah dibatasi pada formulasi daun kelor dengan teh hitam. Tujuan penelitian ini menghasilkan teh hitam daun kelor yang disukai panelis.

\section{METODE PENELITIAN}

\section{Bahan dan Alat}

Bahan yang digunakan untuk pembuatan formulasi teh daun kelor dengan teh hitam adalah daun kelor kering, air dan teh hitam. Di mana alat-alat yang digunakan untuk pembuatan formulasi teh daun kelor dengan teh hitam adalah wadah plastik, alat gelas, alat pengolahan dan alat analisis. 
Metode penelitian yang digunakan adalah metode eksperimen atau percobaan. Rancangan dalam penelitian ini menggunakan Rancangan Acak Lengkap (RAL) faktor tunggal dengan lima taraf dan tiga kali ulangan. Variabel penelitian yaitu formulasi daun kelor dan teh hitam dengan lima taraf yaitu : 75:25; 80:20; 85:15; 90:10, dan 95:5. Mutu teh daun kelor dengan teh hitam yang ditentukan oleh uji fisik, uji kimia, dan uji organoleptik. Uji fisik berupa uji kekentalan (AOAC, 2006); uji kimia berupa pengujian kadar air metode oven (AOAC, 2006), kadar abu metode tanur (AOAC, 2006), kadar lemak Metode Soxhlet (AOAC, 2006), kadar protein (AOAC, 2006), kadar karbohidrat metode Luff Schrool (AOAC, 2006), pH (AOAC, 2006), total padatan terlarut (AOAC, 2006), kadar tanin (Sudarmadji et al, 1984); dan uji organoleptik berupa uji mutu hedonik yang terdiri dari paameter warna, aroma dan rasa serta uji rangking berdasarkan tingkat kesukaan secara keseluruhan (Meilgaard, 2015). Bagan proses pembuatan teh hitam daun kelor disajikan pada Gambar 1.

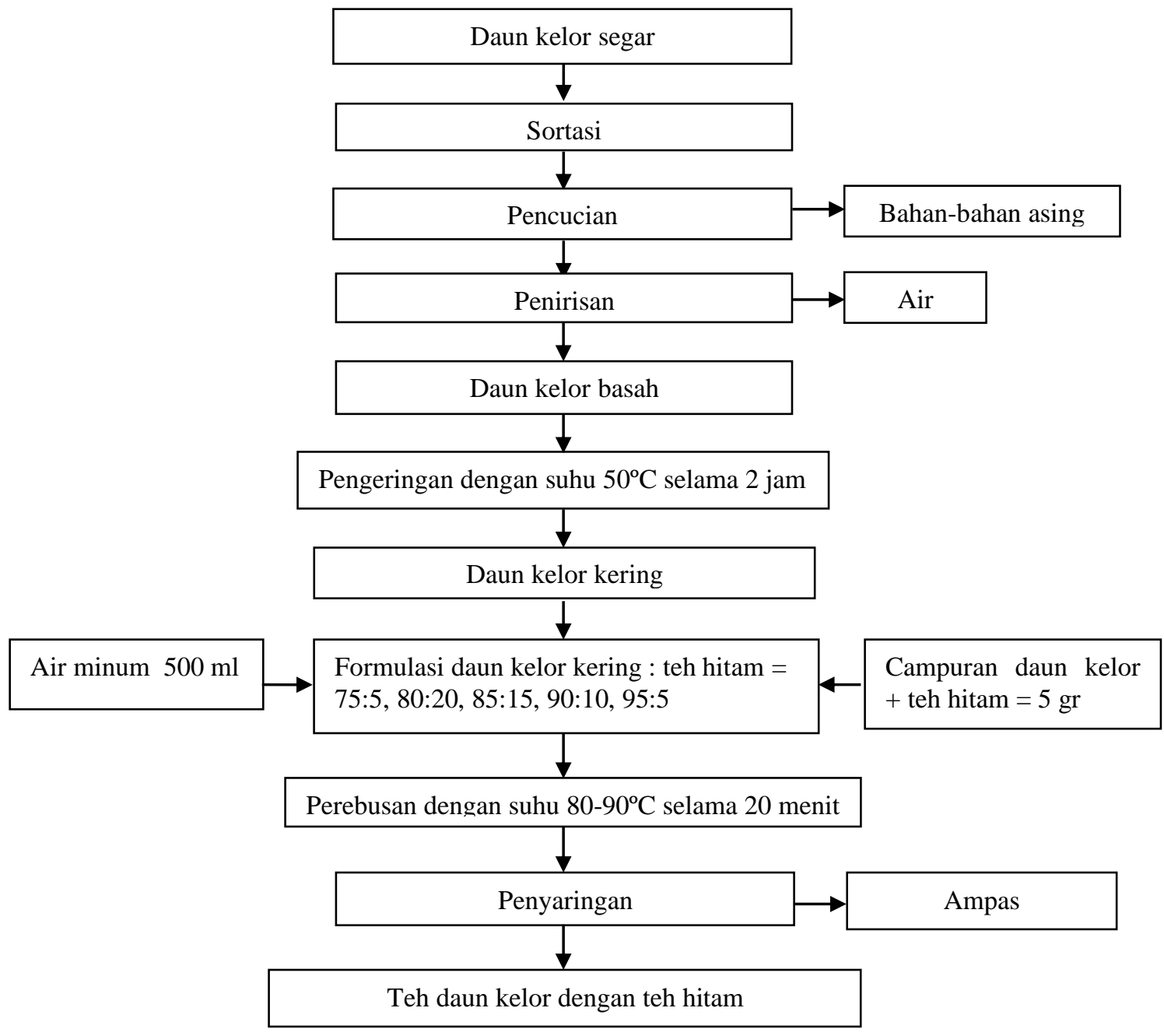

Gambar 1. Diagram alir pembuatan teh daun kelor dengan teh hitam 


\section{HASIL DAN PEMBAHASAN}

Mutu minuman teh daun kelor dengan teh hitam, diuji secara fisik, kimia, dan organoleptik. Data hasil pengujian fisik dan kimia diuraikan pada Tabel 1 dan uji organoleptik pada Tabel 2.

Tabel 1. Nilai rata-rata uji fisik dan uji kimia teh daun kelor dengan teh hitam

\begin{tabular}{|l|c|c|c|c|c|}
\hline \multirow{2}{*}{ Parameter mutu } & \multicolumn{5}{|c|}{ Formulasi teh daun kelor dengan teh hitam } \\
\cline { 2 - 6 } & $\mathbf{7 5 : 2 5}$ & $\mathbf{8 0 : 2 0}$ & $\mathbf{8 5 : 1 5}$ & $\mathbf{9 0 : 1 0}$ & $\mathbf{9 5 : 5}$ \\
\hline Kekentalan (cP) & $2,10 \pm 0,01^{\mathrm{a}}$ & $2,05 \pm 0,06^{\mathrm{a}}$ & $1,90 \pm 0,02^{\mathrm{b}}$ & $1,85 \pm 0,06^{\mathrm{b}}$ & $1,60 \pm 0,03^{\mathrm{c}}$ \\
\hline Kadar air (\%) & $3,23 \pm 0,02$ & $3,22 \pm 0,02$ & $3,21 \pm 0,02$ & $3,20 \pm 0,02$ & $3,19 \pm 0,02$ \\
\hline Kadar abu (\%) & $7,25 \pm 0,02$ & $7,36 \pm 0,03$ & $7,51 \pm 0,04$ & $7,71 \pm 0,03$ & $7,83 \pm 0,03$ \\
\hline Lemak (\%) & $1,10 \pm 0,01$ & $1,11 \pm 0,01$ & $1,12 \pm 0,01$ & $1,13 \pm 0,01$ & $1,14 \pm 0,01$ \\
\hline Protein (\%) & $8,52 \pm 0,05$ & $8,60 \pm 0,01$ & $8,68 \pm 0,00$ & $8,80 \pm 0,01$ & $8,87 \pm 0,01$ \\
\hline Karbohidrat (\%) & $6,25 \pm 0,00^{\mathrm{e}}$ & $7,12 \pm 0,01^{\mathrm{d}}$ & $8,02 \pm 0,01^{\mathrm{c}}$ & $9,02 \pm 0,01^{\mathrm{b}}$ & $10,4 \pm 0,06^{\mathrm{a}}$ \\
\hline Nilai pH & $7,23 \pm 0,03$ & $7,22 \pm 0,02$ & $7,18 \pm 0,03$ & $7,14 \pm 0,03$ & $7,08 \pm 0,02$ \\
\hline TPT $(\%)$ & $5,71 \pm 0,00^{\mathrm{a}}$ & $5,50 \pm 0,00^{\mathrm{b}}$ & $5,31 \pm 0,00^{\mathrm{c}}$ & $5,13 \pm 0,00^{\mathrm{d}}$ & $4,95 \pm 0,00^{\mathrm{e}}$ \\
\hline Kadar tanin (ppm) & $6,23 \pm 0,03^{\mathrm{a}}$ & $5,22 \pm 0,01^{\mathrm{b}}$ & $3,89 \pm 0,03^{\mathrm{bc}}$ & $2,73 \pm 0,01^{\text {cd }}$ & $1,40 \pm 0,03^{\mathrm{d}}$ \\
\hline
\end{tabular}

Keterangan : huruf yang sama pada kolom notasi menunjukkan perbedaan tidak nyata pada $\alpha=0,05$.

Tabel 2. Nilai rata-rata (skor) uji organoleptik seduhan teh daun kelor dan teh hitam dengan formulasi berbeda

\begin{tabular}{|l|c|c|c|c|c|}
\hline \multirow{2}{*}{$\begin{array}{c}\text { Parameter } \\
\text { mutu }\end{array}$} & \multicolumn{5}{|c|}{ Formulasi daun kelor dengan teh hitam } \\
\cline { 2 - 6 } & $\mathbf{7 5 : 2 5}$ & $\mathbf{8 0 : 2 0}$ & $\mathbf{8 5 : 1 5}$ & $\mathbf{9 0 : 1 0}$ & $\mathbf{9 5 : 5}$ \\
\hline Warna & $4,0 \pm 0,2^{\mathrm{b}}$ & $4,4 \pm 0,1^{\mathrm{b}}$ & $5,2 \pm 0,1^{\mathrm{a}}$ & $4,4 \pm 0,1^{\mathrm{b}}$ & $5,0 \pm 0,9^{\mathrm{a}}$ \\
\hline Aroma & $2,7 \pm 0,1$ & $3,0 \pm 0,3$ & $3,1 \pm 0,2$ & $3,1 \pm 0,2$ & $3,2 \pm 0,2$ \\
\hline Rasa & $5,3 \pm 0,2^{\mathrm{a}}$ & $4,5 \pm 0,3^{\mathrm{bc}}$ & $4,2 \pm 0,3^{\mathrm{c}}$ & $4,5 \pm 0,3^{\mathrm{bc}}$ & $4,7 \pm 0,3^{\mathrm{b}}$ \\
\hline Uji Rangking & 5 & 3 & 1 & 2 & 4 \\
\hline
\end{tabular}

Keterangan : huruf yang sama pada kolom notasi menunjukkan perbedaan tidak nyata pada $\alpha=0,05$.

Warna : skor $1=$ sangat hitam, skor $2=$ hitam, skor $3=$ agak hitam, skor $4=$ coklat kehitaman, skor $5=$ coklat, skor $6=$ agak coklat.

Aroma : skor $1=$ sangat langu, skor $2=$ langu, skor $3=$ agak langu, skor $4=$ agak tidak langu, skor $5=$ tidak langu, skor $6=$ sangat tidak langu.

Rasa : Skor 1 = sangat tidak sepat, skor $2=$ tidak sepat, skor $3=$ agak tidak sepat, skor $4=$ agak sepat, skor $5=$ sepat, skor $6=$ sangat sepat.

\section{Kekentalan Minuman Teh Daun Kelor dengan Teh Hitam}

Kekentalan minuman seduhan teh daun kelor dengan teh hitam berkisar antara 1.60-2.10 cP, di mana kekentalan minuman cenderung menurun dengan semakin menurunnya jumlah teh hitam. Kekentalan pada teh dengan formulasi 75:25, 80:20, $85: 15,90: 10$, dan $95: 5$ sebesar 2,10 cP, 2,05 cP, 1,90 cP, 1,85 cP, dan 1,60 cP secara berturut-turut (Tabel 1).

Hasil uji Anava menunjukkan bahwa formulasi teh daun kelor dengan teh hitam memengaruhi kekentalan secara nyata $(\alpha=0,05)$. Hasil uji lanjut Duncan menunjukkan formulasi 95:5 berbeda secara nyata dengan formulasi lainnya, sedangkan formulasi 90:10 dan 85:15 berbeda tidak nyata, demikian juga 80:20 dan 75:25. 
Kekentalan minuman teh daun kelor dan teh hitam menurun dengan semakin rendahnya persentase teh hitam. Hal ini disebabkan teh hitam mengandung katekin, di mana selama proses fermentasi daun teh akan teroksidasi dan katekin akan menjadi ortokuinon yang memadat membentuk theaflavin (TF). Adanya theaflavin dapat menyebabkan minuman teh menjadi lebih kental (Hafezi et al. 2006). Dengan semakin rendahnya teh hitam, maka $\mathrm{TF}$ semakin sedikit, hal inilah yang menyebabkan teh semakin tidak kental.

\section{Kadai air}

Kadar air teh kering hasil formulasi daun kelor dengan teh hitam berkisar antara 3.19-3.23 \% (Tabel 1), di mana kadar air cenderung menurun dengan semakin meningkatnya daun kelor. Kadar air pada teh dengan formulasi 75:25, 80:20, 85:15, 90:10, 95:5, sebesar 3,23\%, 3,22\%, 3,21\%, 3,20\% dan 3,19\% berturut-turut. Hasil uji Anava menunjukkan bahwa formulasi daun kelor dengan teh hitam tidak memengaruhi kadar air secara nyata $(\alpha=0,05)$. Hal ini diduga karena hampir samanya kadar air daun kelor kering dan teh hitam kering, yaitu 2,95\% dan 3,29\% secara berturut-turut. Hal ini sejalan dengan penelitian Haryadi (2011) tentang kadar air daun kelor kering yaitu $<5 \%$ dan kadar air teh hitam berdasarkan penelitian Arifin (1994) yaitu 2,5-3,5\%.

\section{Kadar abu}

Kadar abu bubuk kering formulasi daun kelor dengan teh hitam berkisar antara $7.25 \%$ - 7.83\% (Tabel 1), di mana kadar abu cenderung meningkat dengan semakin meningkatnya daun kelor. Kadar abu pada formulasi 75:25, 80:20, 85:15, 90:10, 95:5 sebesar 7,25\%,7,36\%,7,51\%,7,71\% dan 7,83\% secara berturut-turut.

Hasil uji Anava menunjukkan bahwa formulasi daun kelor dengan teh hitam kering tidak memengaruhi kadar abu secara nyata $(\alpha=0,05)$. Hal ini diduga karena kadar abu daun kelor kering 6,05\% dan kadar abu teh hitam kering 5,5\% yang relatif sama. Kadar abu pada formulasi daun kelor dengan teh hitam tersebut sesuai dengan standar kadar abu teh kering berdasarkan Standar Nasional Indonesia 03-3836-2012 tentang teh kering yaitu maksimal $8 \% \mathrm{~b} / \mathrm{b}$.

\section{Kadar lemak}

Kadar lemak bubuk kering formulasi daun kelor dengan teh hitam cenderung meningkat dengan semakin meningkatnya daun kelor. Kadar lemak pada formulasi $75: 25,80: 20,85: 15,90: 10$, dan 95:5 sebesar $1,10 \%, 1,11 \%, 1,12 \%, 1,13 \%$, dan $1,14 \%$ secara berturut-turut (Tabel 1).

Hasil uji Anava menunjukkan bahwa formulasi daun kelor dengan teh hitam kering tidak memengaruhi kadar lemak secara nyata $(\alpha=0,05)$. Hal ini diduga karena kadar lemak pada daun kelor dan teh hitam kering relatif kecil, yaitu $1,131 \%$ untuk daun kelor dan $0,730 \%$ untuk teh hitam kering. Hal ini sesuai dengan penelitian Fuglie (2001) di mana kadar lemak daun kelor kering sebesar 1,1\% dan kadar lemak teh hitam sebesar 0,7\%. Menurut Departemen Kesehatan RI (1996) kadar lemak teh kering sebesar $0,7 \%$. 


\section{Kadar protein}

Kadar protein pada teh daun kelor dengan teh hitam kering berkisar antara 8,52$8,87 \%$, di mana kadar protein cenderung meningkat dengan semakin meningkatnya daun kelor. Kadar protein teh daun kelor dengan teh hitam kering sebesar 8,52\%, $8,60 \%, 8,68 \%, 8,80 \%$, dan $8,87 \%$ untuk formulasi $75: 25,80: 20,85: 15,90: 10$, dan 95:5 secara berturut-turut (Tabel 1).

Hasil analisis Anava menunjukkan bahwa formulasi daun kelor dengan teh hitam tidak memengaruhi kadar protein secara nyata $(\alpha=0,05)$. Peningkatan kadar protein dengan semakin tingginya formulasi daun kelor disebabkan lebih tingginya kadar protein daun kelor dibandingkan teh hitam, yaitu 6,13\% untuk daun kelor dan 1,95\% untuk teh hitam.

\section{Kadar karbohidrat}

Kadar karbohidrat teh daun kelor dengan teh hitam berkisar antara 6,25 - 10,04\%, di mana kadar karbohidrat cenderung meningkat dengan semakin meningkatnya daun kelor. Kadar karbohidrat teh daun kelor dengan teh hitam sebesar 6,25\%, 7,12\%, $8,02 \%, 9,02 \%$ dan $10,04 \%$ pada formulasi 75:25, 80:20, 85:15, 90:10 dan 95:5 secara berturut-turut (Tabel 1).

Hasil uji Anava menunjukkan bahwa formulasi teh daun kelor dengan teh hitam berbeda memengaruhi kadar karbohidrat secara nyata $(\alpha=0,05)$. Hasil uji Duncan menunjukkan bahwa formulasi teh daun kelor dengan teh hitam berbeda secara nyata $(\alpha$ $=0,05)$ untuk semua perlakuan. Hal ini diduga karena jumlah karbohidrat pada daun kelor lebih tinggi $(11,812 \%)$ dibandingkan teh hitam $(5,633 \%)$.

\section{Nilai $\mathrm{pH}$}

Nilai $\mathrm{pH}$ air seduhan teh daun kelor dengan teh hitam berkisar antara 7,08 - 7,23 yang menunjukan cenderung menurun dengan semakin menurunnya teh hitam. Nilai pH formulasi teh daun kelor dengan teh hitam sebesar 7,23, 7,22, 7,18, 7,14, dan 7,08 pada formulasi 75:25, 80:20, 85:15, 90:10 dan 95:05 secara berturut-turut (Tabel 1).

Hasil uji Anava menunjukkan bahwa formulasi teh daun kelor dengan teh hitam berbeda tidak memengaruhi nilai $\mathrm{pH}$ secara nyata $(\alpha=0,05)$. Nilai rata-rata $\mathrm{pH}$ teh daun kelor dengan teh hitam cenderung basa. Hal ini diduga karena selama proses pengolahan dapat terjadi proses oksidasi dari komponen polifenol menghasilkan theaflavin. Jika oksidasi berlanjut, maka theaflavin akan berubah menjadi thearubigin. Semakin sedikit thearubigin yang terbentuk maka $\mathrm{pH}$ akan semakin naik, karena theaflavin bersifat asam lemah dan thearubigin bersifat asam kuat (Lelani, 1995). Perebusan memberikan pengaruh terhadap makin banyaknya komponen yang terekstrasi sehingga theaflavin yang ada pada sampel mengalami oksidasi yang berakibat air rebusan teh daun kelor dengan teh hitam cenderung lebih gelap.

\section{Total padatan terlarut (TPT)}

Nilai TPT air seduhan teh daun kelor dengan teh hitam cenderung menurun dengan semakin menurunnya teh hitam. Nilai TPT sebesar 5,71\%, 5,50\%, 5,31\%, 
$5,13 \%$, dan 4,95\% pada formulasi 75:25, 80:20, 85:15, 90:10, 95:05 secara berturutturut (Tabel 1).

Hasil uji Anava menunjukkan bahwa formulasi teh daun kelor dengan teh hitam berbeda memengaruhi nilai total padatan terlarut secara nyata $(\alpha=0,05)$. Hasil analisa lanjutan (uji Duncan) menunjukkan bahwa setiap taraf formulasi memengaruhi TPT secara berbeda nyata $(\alpha=0,05)$. Formulasi teh hitam yang semakin banyak menyebabkan kandungan bahan yang terlarut di dalam larutan juga semakin tinggi. Hal ini karena pada saat pemanasan theaflavin dan thearubigin dalam teh hitam akan larut sehingga meningkatkan TPT air seduhan.

\section{Kadar tanin}

Kadar tanin air seduhan teh daun kelor dengan teh hitam berkisar antara 1,40 $6,23 \mathrm{ppm}$, di mana kadar tanin cenderung menurun dengan semakin menurunnya teh hitam. Nilai kadar tanin sebesar 6,23 ppm, 5,22 ppm, 3,89 ppm, 2,73 ppm dan 1,40 ppm pada formulasi 75:25, 80:20, 85:15, 90:10 dan 95:05 secara berturut-turut (Tabel $1)$.

Hasil uji Anava menunjukkan bahwa formulasi teh daun kelor dengan teh hitam berbeda memengaruhi nilai kadar tanin secara nyata $(\alpha=0,05)$. Hasil analisa lanjutan (uji Duncan) menunjukkan bahwa formulasi 75:25 memberikan pengaruh yang berbeda nyata terhadap formulasi lainnya, sedangkan formulasi lainnya memberikan pengaruh yang sama. Secara umum, kandungan tanin pada daun teh sekitar 9-20 ppm (Suryaningrum 2007) sedangkan daun kelor 1,4 ppm (Foild, dkk. 2007). Pada teh hitam, kandungan tanin menurun pada saat fermentasi, yaitu terjadinya proses oksidasi enzimatis yang dilakukan selama 1-5 jam (Sujayanto, 2008). Hal ini sejalan dengan Rohdiana (2007), di mana proses oksidasi enzimatis dapat mengubah sebagian tanin menjadi senyawa turunan yaitu theaflavin dan thearubigin. Dengan terbentuknya senyawa turunan maka kadar tanin dalam daun teh akan berkurang, sehingga kadar tanin teh hitam (teh yang diolah dengan proses oksidasi enzimatis) menjadi lebih rendah. Kadar tanin juga menurun disebabkan perlakuan pengeringan (Sayuti 2010) karena pada saat pengeringan terjadi reaksi oksidasi enzimatis.

\section{Warna}

Warna seduhan minuman teh daun kelor dan teh hitam berkisar antara coklat kehitaman - coklat (skor 4-5,2), di mana warna minuman teh cenderung semakin coklat dengan semakin meningkatnya jumlah daun kelor (Tabel 2). Hasil uji Anava formulasi teh daun kelor dengan teh hitam berbeda memengaruhi warna air seduhan teh secara nyata $(\alpha=0,05)$. Hasil analisa lanjutan (uji beda rata-rata Duncan) menunjukkan bahwa formulasi teh daun kelor dengan teh hitam 75:25, 80:20, 90:10 memberikan pengaruh yang sama terhadap warna air seduhan dan pengaruh yang berbeda pada formulasi 85:15 dan 95:5.

Mengingkatnya warna seduhan minuman teh daun kelor dengan teh hitam diduga terkait dengan proses perebusan. Perebusan mengakibatkan teroksidasinya senyawa flavanol menjadi senyawa fenol yang kemudian senyawa fenol tersebut akibat adanya pemanasan mengalami oksidasi menghasilkan kuinon. Oksidasi kuinon lebih lanjut menghasilkan thearubigin yang mengakibatkan formulasi teh daun kelor dengan teh 
hitam yang direbus menjadi tampak lebih gelap, karena thearubigin memberi kombinasi warna merah kecoklatan (Sujayanto, 2008).

\section{Aroma}

Aroma air seduhan teh daun kelor dengan teh hitam berkisar agak langu (skor 2,73,2 ) untuk semua formulasi (Tabel 2). Hasil uji Anava formulasi teh daun kelor dengan teh hitam berbeda tidak memengaruhi aroma air seduhan teh secara nyata $(\alpha=0,05)$. Aroma semua formulasi seduhan teh daun kelor dan teh hitam adalah agak langu. Hal ini karena adanya senyawa katekin. Senyawa ini tidak berwarna, larut dalam air, serta membawa sifat pahit dan sepat pada seduhan teh dan memberi aroma khas teh (Putratama, 2009).

\section{Rasa}

Rasa minuman seduhan teh daun kelor dengan teh hitam berkisar antara agak sepat - sepat (skor 4,2 - 5,3). Rasa sepat minuman cenderung berkurang dengan semakin sedikitnya teh hitam (Tabel 2). Hasil uji Anava menunjukkan bahwa formulasi teh daun kelor dengan teh hitam berbeda memengaruhi rasa seduhan teh daun kelor dengan teh hitam secara nyata $(\alpha=0,05)$. Hasil uji lanjut Duncan menunjukkan formulasi teh daun kelor dengan teh hitam 75:5 memberikan pengaruh yang berbeda terhadap rasa formulasi teh daun kelor dengan teh hitam lainnya. Di mana formulasi lainnya memberikan pengaruh yang sama terhadap rasa seduhan minuman teh daun kelor dengan teh hitam. Rasa sepat pada minuman diduga terkait dengan adanya senyawa tanin pada teh hitam. Tanin akan membentuk ikatan silang dengan protein atau glikoprotein di rongga mulut sehingga menimbulkan perasaan kering dan berkerut (Jamriati, 2008).

\section{Uji Rangking}

Uji rangking pada air seduhan teh daun kelor dan teh hitam dilakukan berdasarkan kesukaan panelis secara umum. Hasil uji menunjukkan bahwa panelis paling menyukai formulasi teh daun kelor dengan teh hitam 85:15 (Tabel 2). Di mana semakin banyak penggunaan daun kelor kering memberikan nilai yang semakin menurun. Karakteristik air seduhan teh daun kelor dengan teh hitam formulasi 85:15 adalah berwarna coklat, beraroma agak langu, dan berasa agak sepat. Rangking terendah ditemukan pada formulasi teh daun kelor dengan teh hitam 75:25. Karakteristik minuman ini adalah berwarna coklat kehitaman, beraroma agak langu dan berasa sepat.

\section{KESIMPULAN}

Berdasarkan uraian di atas, formulasi teh daun kelor dengan teh hitam memengaruhi kekentalan, kadar karbohidrat, TPT, kadar tanin, warna dan rasa minuman secara nyata $(\alpha=0,05)$, namun tidak memengaruhi kadar air, kadar abu, kadar lemak, kadar protein, $\mathrm{pH}$ dan aroma secara nyata $(\alpha=0,05)$. 
Hasil uji rangking menunjukkan formulasi teh daun kelor dengan teh hitam 85:15 merupakan rangking tertinggi. Karakteristik air seduhan teh daun kelor dengan teh hitam formulasi 85:15 adalah berwarna coklat, beraroma agak langu, dan berasa agak sepat, kekentalan 1,90 cP, kadar air 3,21\%, kadar abu 7,51\%, kadar lemak 1,12\%, kadar protein 8,68\%, kadar karbohidrat 8,02\%, pH 7.18, TPT 5,31\% dan kadar tanin 3,89 ppm. Formulasi ini sesuai dengan SNI 01-3143-1992, khususnya nilai positif untuk uji tanin.

\section{SARAN}

Berdasarkan hasil penelitian dan pembahasan, disarankan untuk membuat formulasi teh daun kelor dengan teh hitam dalam bentuk teh celup sehingga penyajiannya akan lebih cepat, mudah dan praktis.

\section{DAFTAR PUSTAKA}

AOAC. (2006). Official methods of analysis. Washington DC: Association of Official Analytical Chemist.

Arifin, S. (1994). Petunjuk Teknis Pengolahan Teh. Pusat Penelitian Teh dan Kina Gambung. Bogor.

Badan Standarisasi Nasional. (2012). Syarat teh kering sesuai standar SNI 03-38362012. Departemen Perindustrian RI. Jakarta.

Damayanthi, E., Kusharto, C.M., Suprihatini, R., Rohdiana, D. (2008). Studi Kandungan Katekin dan Turunannya sebagai Antioksidan Alami serta Karakteristik Organoleptik Produk Teh Murbei dan Teh Camellia - Murbei. Media Gizi dan Keluarga 32 (1): 95-103.

Departemen Kesehatan R.I. (1996). Daftar Komposisi Bahan Makanan. Bhratara Karya Aksara, Jakarta.

Foild N, Makkar HPS \& Becker. (2007). The Potential of Moringa Oleifera for Agricultural and Industrial Uses.

Fuglie, L.J. (2001). The Miracle Tree: Moringa Oleifera: Natural Nutrition for the Tropics. Training Manual. Church World Service, Dakar, Senegal.

Hafezi, M., Nasernejad, B \& Vahabzadeh, F. (2006). Optimation of fermentation time for Iranian black tea production. Iran J Chem Chem. Eng 25: 39-4.

Haryadi, N.K (2011). Kelor herbal Multikhasiat Ampuh Melawan diabetes Mellitus, Kolesterol Tinggi dan Penyakit Lainnya. Surakarta: Delta Media.

Jamriati, R. (2008). Pangan tradisional, Alternatif makanan pokok. http://beritaiptek.com. 
Vol 1, No. 1, 2018

Lelani, Y.R. (1995). Optimalisasi Kondisi Ekstraksi Teh Wangi pada industri Teh Botol. Skripsi Sarjana Fakultas Teknologi Pertanian, IPB, Bogor.

Machfoedz, M.K. (2008). Pengetahuan Bahan Baku Teh. LPP Kampus, Yogyakarta.

Manik, D.M.T. (2014). Mempelajari Pengaruh Lama Pelayuan Dan Penambahan Teh Sirsak Terhadap Mutu Teh Hitam. Jurusan Teknologi Pertanian, Fak. Pertanian, Universitas Sumatra Utara.

Meilgaard, M., Civille, G.V \& Carr, B.T. (2015). Sensory evaluation techniques. 5th ed. CRC Press.

Putratama, M.S.W. (2009). Pengolahan Teh Hitam Secara CTC di PT. Perkebunan Nusantara VIII. Universitas Gadjah Mada, Yogyakarta.

Putri, T.W.M. (2014). Uji Kalsium dan Organoleptik Teh Kombinasi Daun Sirsak \& Kulit Buah Naga Merah Dengan Variasi Suhu Pengeringan. Jurusan Biologi. Fak. Keguruan \& Ilmu Pendidikan. Universitas Muhammadiyah Jakarta.

Rohdiana, D. (2007). Petunjuk Teknis Pengolahan Teh. Pusat Penelitian Teh dan Kina. Gambung.

Roni, M.A. (2008). Formulasi minuman herbal instan antioksidan dari campuran teh hijau (Camellia sinensis), Pegagan (Centella asiatica), dan daun jeruk purut (Cytus hystrix). Skripsi S1. Institut Pertanian Bogor.

Sayuti, K., Taib, G \& Hilma, L. (2010). Pengaruh perlakuan pendahuluan pada daun murbei (morus alba 1) terhadap karakteristik minuman effervescent yang dihasilkan. Laporan Penelitian. Teknologi Hasil Pertanian. Universitas Andalas.

Simbolan, J.M., Simbolan, M., Katharina, N. (2007). Cegah Malnutrisi dengan Kelor. Yogyakarta: Penerbit Kanisius.

Sujayanto, G. (2008). Khasiat Teh Untuk Kesehatan dan Kecantikan. Flona Serial hal. 34-38. Jakarta : ITB.

Suryaningrum, R.D., Sulthon, M., Prafiadi, S \& Maghfiroh, K. (2007). Peningkatan kadar tanin dan penurunan kadar klorin sebagai upaya peningkatan nilai guna teh celup. Program Kreativitas Mahasiswa. Penulisan Ilmiah. Universitas Muhammadiyah Malang.

Tuminah, S. (2004). Teh (Camellia sinensis O.K. var. Assamica (Mast)) sebagai Salah Satu Sumber Antioksidan. Cermin Dunia Kedokteran No.144. 